\title{
ASSESSMENT OF DABENA MINI HYDRO POWER PLANT AT DABENA RIVER
}

\author{
Tadele Abera ${ }^{*}{ }^{\otimes}$, Firew Dereje ${ }^{2}$ \\ ${ }^{*}$ Addis Ababa University, Ethiopia \\ 2 Mettu University, Ethiopia
}

DOI: https://doi.org/10.29121/ijetmr.v7.i11.2020.810

Article Citation: Tadele Abera, and Firew Dereje. (2020). ASSESSMENT OF DABENA MINI HYDRO POWER PLANT AT DABENA RIVER. International Journal of Engineering Technologies and Management Research, 7(11), 30-38. https://doi.org/10.29121/ijetmr.v7 i11.2020.810

Published Date: 19 November 2020

\section{Keywords:}

Generator

Hydropower

Open Channel

Penstock

Turbine

Weir

\begin{abstract}
The number of electricity users is increasing with the increase of fuel cost and environmental pollution. The mini hydro power has grown as an alternative energy source that can be easily constructed with the minimal environmental impact. This research access the mini hydro power plant implemented on Dabena River 50 years ago by German missionaries. But it is not functioning these days. The available Gross head of the river measured using a GPS receiver and was found to be $11.5 \mathrm{~m}$. It has a potential for producing $150 \mathrm{KW}$. With this output power, we can supply Bedelle Agricultural and Forestry College under Mettu University and nearby rural area. Having the head, flow rate and output power of the river into consideration, the turbine selected was cross flow turbine with specific speed of $243 \mathrm{rpm}$, runner diameter of $52 \mathrm{~cm}$, runner length of $82 \mathrm{~cm}$, blade radius $17 \mathrm{~cm}$ and blade number of 18.24 poles synchronous motor was selected as the Generator with rotational speed of $250 \mathrm{rpm}$. International renewable energy agency cost analysis was used to analyze financial viability of the project. The annual energy production estimated was $289,908 \mathrm{kwh}$ and the anticipated revenue to be generated is $136,256 \mathrm{birr}$. The initial cost of the project estimated to be 2.475 million birr.
\end{abstract}

\section{INTRODUCTION}

Hydro-power is most common and widely used resource of electric power generation. Around 1880 the generation of electricity derived from hydro-turbines, and the capacity of installation worldwide has grown at about $5 \%$ per year since. $20 \%$ of world's electric generation is now from hydro power [1], [2]. Output depends on the terrain and rainfall. Hydro-power is defined as generating electric power from falling water. It is energy from water sources such as the rivers, ocean, and waterfalls. The power or energy of flowing water is harnessed by turbines, which are placed in the path of the water flow. The force exerted by water moving over turbine blades rotates the turbine runner; the turbine runner rotates the generator, which produces electricity. 


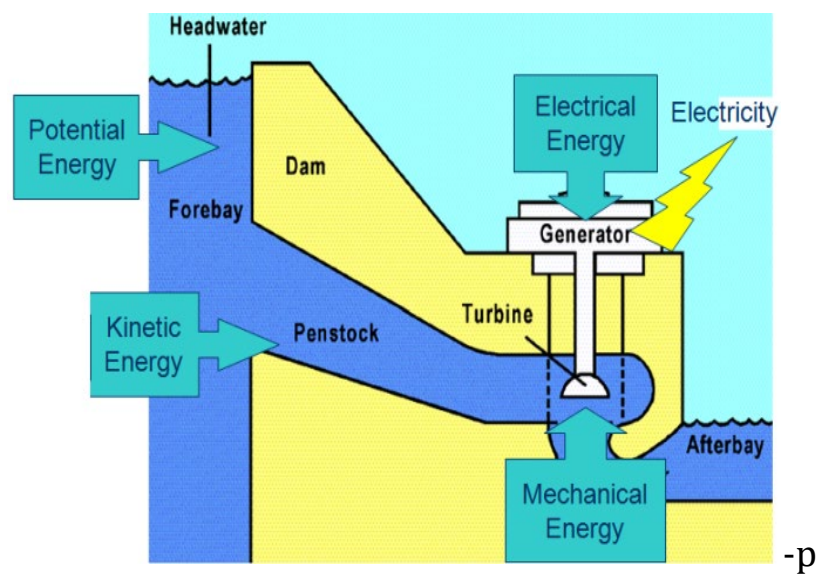

Figure 1: The general flow of Hydro power plant [2]

Water is required to run electric generating unit. It's held in a lake behind the dam, and the water force released from the lake via the dam spin the turbine blades. The electricity can be produced in such a way that turbine is connected to the generator. The water that passes the turbine, joins the river on the down side of the dam.

\subsection{MINI-HYDRO POWER}

Mini-hydro can be applied ranging from electrifying a single user to a number of few users with hundreds of kilowatts to be sold for National Grid or to be used as standalone. Small-scale hydropower is one of most considered technology that provides clean electricity production.

The key advantages are [2]:

1) It is highly efficient (70 - 90\%).

2) Its capacity factor is high (typically $>50 \%$ ).

3) It is easily predictable.

4) Its rate of change is slow.

5) It is highly correlated with demand.

6) It is highly robust technology.

In this work we have assessed a mini HPP at Dabena river, which is located at the geographical coordinates latitude $08^{\circ} 24^{\prime} \mathrm{N}$ and longitude e $36^{\circ} 18^{\prime} \mathrm{E}$ near to Bedele agricultural and forestry college of Mettu university. Debena MHPP was designed and implemented 50 years ago by German missionaries to provide an electric power to Debena TVET College. Unfortunately this MHPP is not functioning these days. The driving forces that motivated us to conduct this research are: (i) Bedelle substation is highly loaded so that Bedelle agricultural and Forestry College introduce a high interruption of power (ii) Rural area peoples around Debena river needs electric power as EEPCO power hasn't addressed.

The rest of the paper is organized as follows. Section 2, assessment of civil work components. Section 3, assessment of electromechanical components. Section 4, contains economic analysis of MHPP and section 5 concludes the paper.

\section{ASSESSMENT OF CIVIL WORK COMPONENTS}

The primary data from field work as well as secondary data obtained from Bedelle Meteorology station has been used to conduct this research. Both primary and secondary data are put in tables bellow

Table 1: Primary Data from Field Survey Direct Measurement

\begin{tabular}{|c|c|}
\hline Data Collected & Value \\
\hline Gross Head of the river & $11.5 \mathrm{~m}$ \\
\hline
\end{tabular}


Tadele Abera, and Firew Dereje

\begin{tabular}{|c|c|}
\hline Flow rate of the river & $98.2\left(\mathrm{~m}^{3} / \mathrm{s}\right)$ \\
\hline Weir Length and depth & $30 \mathrm{~m}$ and $1.5 \mathrm{~m}$ respectively \\
\hline Forebay tank Length, width and depth & $\begin{array}{c}4.5 \mathrm{~m}, 2.5 \mathrm{~m} \text { and } 1.9 \mathrm{~m} \\
\text { respectively }\end{array}$ \\
\hline Penstock length and diameter & $\begin{array}{c}60 \mathrm{~m} \text { and } 0.9 \mathrm{~m} \\
\text { respectively }\end{array}$ \\
\hline Open channel length and depth & $145 \mathrm{~m}, 1.3 \mathrm{~m}$ respectively \\
\hline
\end{tabular}

Because the share of the civil work to the total cost of a MHP system is not less than $30 \%$, proper design of this part of a system is vital [1]. Not only is this but also there are other reasons that make the proper and careful design of the civil work vital. For example, it is this component which will drive the required flow rate to the turbine and which creates the required head. Therefore, civil work components design should be done carefully and most of the time it accounts more than $60 \%$ of the overall design of a MHP system [1]. Here under is the assessment of design of some civil work components depending on the available head and flow rate at the site considered.

\subsection{OPEN CHANNEL}

- Manning coefficient for well finished cement is 0.012 [4]

- Rectangular Type open channel that has $145 \mathrm{~m}$ length from the weir to forebay tank.

- Nominal velocity (V) of water flow in the channel is $1.28 \mathrm{~m} / \mathrm{s}$

- Net head of Debena MHEPP is $10 \mathrm{~m}$

$\mathrm{L}=145 \mathrm{~m}$

$\mathrm{W}=1.3 \mathrm{~m}$

$\mathrm{H}=1 \mathrm{~m}$

Where $\mathrm{L}=$ channel length

$\mathrm{W}=$ channel width

$\mathrm{H}=$ channel height

$\mathrm{A}=\mathrm{W} \times \mathrm{H}=1.3 \times 1$

$\mathrm{A}=1.3 \mathrm{~m}^{2}$

$\mathrm{Q}=\mathrm{A} \times \mathrm{V}$

Where $A=$ area of open channel

$\mathrm{Q}=$ flow rate of the open channel

$\mathrm{Q}=1.3 \times 1.28=1.664 \mathrm{~m}^{3} / \mathrm{S}$

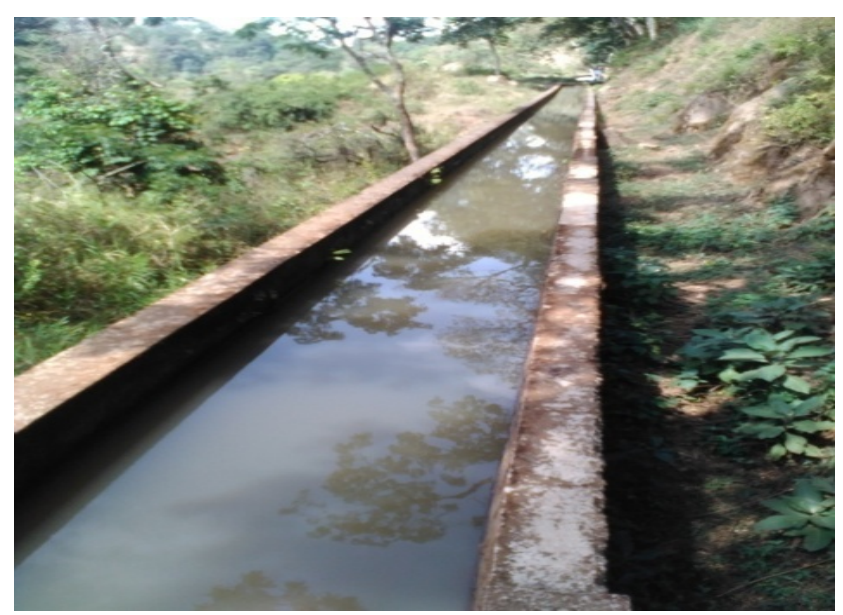

Figure 2: Open channel of the plant 


\subsection{WEIR}

For the rivers with low discharges (usually < 4 cubic meter per second); weir may be built. Weir can be restricted as it is a small wall or dam in the stream that can be measured with a notch with which overall water will be channeled. We can calculate the flow rate of rectangular body as follow [4]:

$\mathrm{Q}=1.8^{*}(\mathrm{~W}-0.2 \mathrm{~h}) * \mathrm{~h}^{1.5}$

With,

W= Width of the Weir in (m)

$\mathrm{h}=$ Heightof Weir in $(\mathrm{m})$

For Debena River case:

Weir length $30 \mathrm{~m}$ and height $1.5 \mathrm{~m}$

$\mathrm{Q}=1.8 *(\mathrm{~W}-0.2 \mathrm{~h}) * \mathrm{~h}^{1.5}$

$\mathrm{Q}=1.8 *(30-0.2 * 1.5) * 1.51 .5$

$\mathrm{Q}=98.2 \mathrm{~m}^{3} / \mathrm{s}$

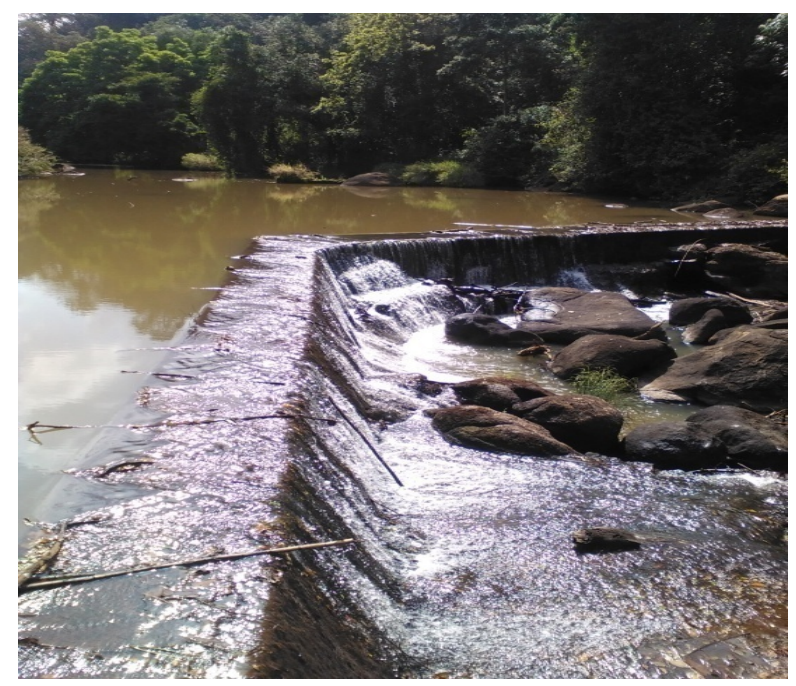

Figure 3: Weir of the plant

\subsection{FOREBAY TANK}

$$
\begin{aligned}
& \mathrm{H}=1.9 \\
& \mathrm{~W}=2.5 \\
& \mathrm{~L}=4.5 \\
& \text { Where } \mathrm{L} \text { = forebay length } \\
& \quad \mathrm{W}=\text { forebay width } \\
& \mathrm{H}=\text { forebay height }
\end{aligned}
$$

The water volume it contains can be calculated as:

$\mathrm{V}=\mathrm{HxWxL}=1.9 \times 1.5 \times 4.5$

$\mathrm{V}=21 \mathrm{~m}^{3}$

The water storage time is

$\mathrm{V}=\mathrm{Q} \times \mathrm{T}$

$\mathrm{T}=\mathrm{V} / \mathrm{Q}$

$\mathrm{T}=21$ second 


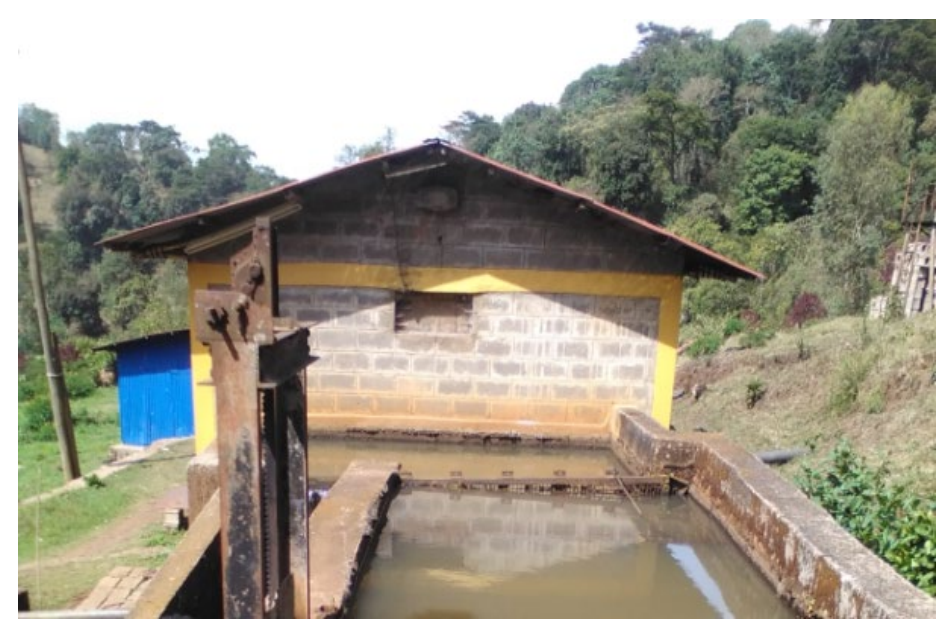

Figure 4: Forebay tank of the plant

\section{ASSESSMENT OF ELECTROMECHANICAL COMPONENTS}

Under this topic we have assessed electromechanical components such as Penstock, Turbine and Generator with reasonable engineering criteria.

\subsection{PENSTOCK DESIGN}

To transfer water to power house from the intake, Penstocks (pipes) are used. There are two possibilities to install pipes: over and under the ground. This is basically relies on factors such as the ground nature, materials where the penstock is made, temperature and the effect of the environment. The penstock in our case is underground. The estimated flow rate, length of the pipe and gross head are used to calculate the internal diameter rof penstock (Dp) as $[4]$.

$$
D_{p}=2.69 *\left(n_{p}^{2} * Q^{2} * L_{p} / H_{g}\right)^{0.1875}
$$

With

$\mathrm{n}_{\mathrm{p}}=$ Manning's coefficient.

$\mathrm{Q}=$ the flow rate of water in $\left(\mathrm{m}^{3} / \mathrm{s}\right)$.

$\mathrm{L}_{\mathrm{p}}=$ penstock length $(\mathrm{m})$.

$\mathrm{H}_{\mathrm{g}}=$ gross head $(\mathrm{m})$.

The penstock thickness relies on the materials of the pipe, its tensile strength, and diameter of the Pipe and on the pressure where it operates.

We can calculate the minimum thickness of the pipe wall as [4]:

$t_{p}=\frac{D_{p}+508}{400}+1.2 \quad(m m)$

With

$\mathrm{Dp}=$ Diameter of the penstock in $(\mathrm{mm})$.

$\mathrm{tp}=$ Minimum thickness of the penstock in (mm).

The pipe (welded steel) has capacity to withstand deformation in the field.

$\mathrm{Hg}=11.5 \mathrm{~m}$

$\mathrm{Q}=1.664 \mathrm{~m}^{3} / \mathrm{s}$

Penstock length $=30 \mathrm{~m}$

Where, $\mathrm{Hg}=$ gross head

$\mathrm{Q}=$ Design Discharge

$\mathrm{n}=$ roughness coefficient

International Journal of Engineering Technologies and Management Research 
$\mathrm{L}=$ length of penstock

$D_{p}=2.69 *\left(n_{p}{ }^{2} * Q^{2} * L_{p} / H_{g}\right)^{0.1875}$

$\mathrm{Dp}=2.69 *\left(0.012^{\wedge} 2 * 1.664^{\wedge} 2 * 60 / 11.5\right)^{0.1875}$

$\mathrm{Dp}=0.85 \mathrm{~m}$ or $85 \mathrm{~cm}$

$$
t_{p}=\frac{D_{p}+508}{400}+1.2 \quad(\mathrm{~mm})
$$

$$
\begin{gathered}
\text { tp }=\frac{850+508}{400}+1.2 \\
t p=4.6 \mathrm{~mm}
\end{gathered}
$$

\subsection{TURBINE POWER}

Falling water is the major factor that determines generation of all hydro-electric power. We can calculate the generated power in the turbine regardless of the path of the water in pen stock or in an open channel as: [4]

$\mathbf{P}_{\mathbf{t}}=\mathrm{r}^{*} \mathrm{~g}^{*} \mathbf{H}_{\mathbf{n}} * \mathbf{Q} * \eta_{\mathbf{t}}$ (watt)

$\mathbf{P}_{\mathbf{t}}=$ Generated turbine shaft power in Watt

$\mathrm{r}=$ Density of water $=1000 \mathrm{~kg} / \mathbf{m}^{3}$

$H_{n}=$ net head $(\mathrm{m})$

$\mathrm{Q}=$ Flow rate of the water in $\left(\mathrm{m}^{3} / \mathbf{s}\right)$

$\mathrm{g}=$ gravitational constant $\left(9.8 \mathrm{~m} / \mathrm{s}^{2}\right)$

$\eta_{t}=$ turbine efficiency (Normally $80-90 \%$ )

From the above parameters, the output power we can obtain from the River can be:

$$
\begin{gathered}
\mathrm{Pt}=1000 \frac{\mathrm{kg}}{\mathrm{m}^{3}} * 9.81 \frac{\mathrm{m}}{\mathrm{s}} * 11.5 \mathrm{~m} * 1.664 \frac{\mathrm{m}^{3}}{\mathrm{~s}} * 0.8 \\
\mathrm{Pt}=150 \mathrm{kw}
\end{gathered}
$$

\subsection{TURBINE SELECTION}

Turbine selection is based on the output of turbine and available head for the site. From the turbine application chart below, the turbine for this plant is Cross flow turbine.

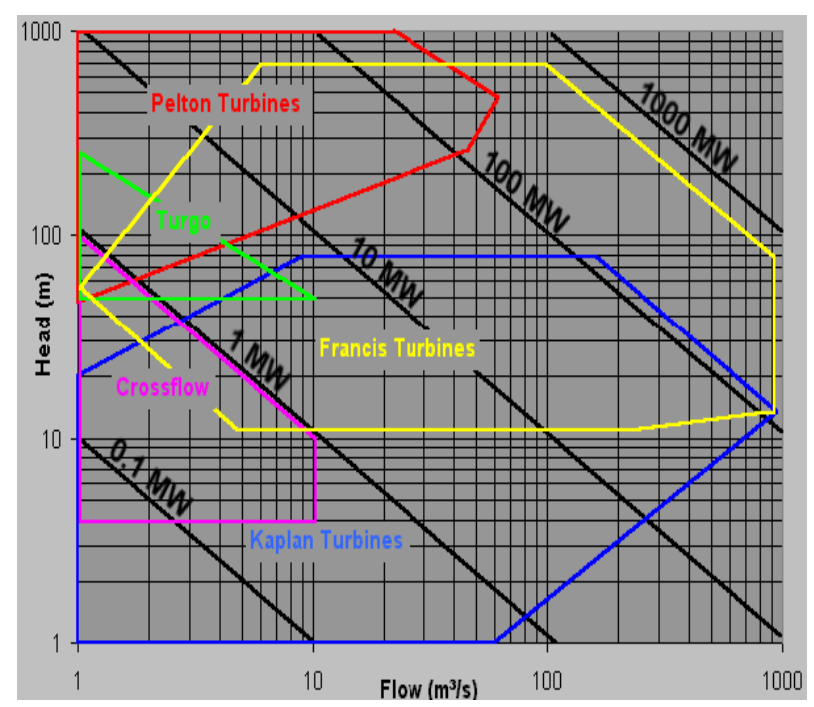

Figure 5: Turbine application chart [4]

Cross flow turbine has high efficiency at low head and fabricated easily in local companies. After determining the turbine type, we can easily estimate the turbine dimensions [18], [13]. 


\subsection{GENERATOR SELECTION}

The generator selection is based on the advantages we can get for intended site. Thus, the suitable turbine for our plant is synchronous generator due to the following reasons [18]. It provides voltage regulation, frequency and phase angle control. Because of excitation do not depend on grid Synchronous generators can isolately run from grid and then generate power. Pole calculation of synchronous generator

No $=\frac{120 * f}{P}$
$P=120 * \frac{f}{N o}$

Where, $\mathrm{No}=$ is rated rotational speed, $\mathrm{No}=243 \mathrm{rpm}$

$\mathrm{f}=$ is frequency $=50 \mathrm{~Hz}$

$\mathrm{p}=$ pole $=24$

Standard rated speed for 24 pole synchronous generator is $250 \mathrm{rpm}$.

The gearing ratio can be calculated as

$\mathrm{G}=\frac{\text { alternator rpm }}{\text { turbine rpm }}$

$\mathrm{G}=\frac{250}{243}=1.02$

For better coupling system the speed of generator must match the speed of turbine. Since the speed of turbine is fixed the speed of generator increase or decrease via gear to match with the speed of turbine. In our case we have coupled our system with gear of gearing ratio 1.02 .

\section{ECONOMIC ANALYSIS OF MHPP}

\subsection{LOAD ESTIMATION FOR BEDELLE CAMPUS AND NEAR LOCAL HOUSE HOLD}

Table 2: Load Estimation for Bedelle Campus

\begin{tabular}{|c|c|c|c|c|c|c|}
\hline No & $\begin{array}{c}\text { Load } \\
\text { (device) }\end{array}$ & $\begin{array}{c}\text { Connected } \\
\text { load(kw) }\end{array}$ & $\begin{array}{c}\text { Operation } \\
\text { hours perr } \\
\text { day }\end{array}$ & $\begin{array}{c}\text { Operation } \\
\text { Day per } \\
\text { year }\end{array}$ & $\begin{array}{c}\text { Operatio } \\
\text { n hours } \\
\text { per year }\end{array}$ & $\begin{array}{c}\text { Demand } \\
\text { kwh per } \\
\text { year }\end{array}$ \\
\hline 1 & Lamp & 52 & 8 & 300 & 2400 & 124800 \\
\hline 2 & $\begin{array}{c}\text { Straight } \\
\text { light }\end{array}$ & 10 & 12 & 300 & 3600 & 36000 \\
\hline 3 & $\begin{array}{c}\text { Electric } \\
\text { mitad }\end{array}$ & 33 & 3 & 300 & 900 & 29700 \\
\hline 4 & $\begin{array}{c}\text { Electric } \\
\text { stove }\end{array}$ & 21.12 & 3 & 300 & 900 & 19008 \\
\hline 5 & $\begin{array}{c}\text { Flour Mill } \\
\text { load }\end{array}$ & 20 & 2 & 300 & 600 & 12000 \\
\hline 6 & $\begin{array}{c}\text { Office } \\
\text { appliance }\end{array}$ & 60 & 8 & 300 & 2400 & 144000 \\
\hline 7 & $\begin{array}{c}\text { Local } \\
\text { community } \\
\text { load(100 } \\
\text { house) }\end{array}$ & 20 & 6 & 300 & 1800 & 36000 \\
\hline \multicolumn{7}{|c|}{ Total load (kw)=147.12 kw } \\
Total Demand Per Year (Kwh/Year) $=289,908$ Kwh
\end{tabular}


According to Ethiopian electric utility price rate, the average price for $1 \mathrm{kwh}$ is $0.47 \mathrm{birr}$. Therefore, the total revenue will be 136256.76 birr per year.

\subsection{AVERAGE INVESTMENT COSTS}

The large hydropower plants average investment cost with storage is in the range between USD $1050 / \mathrm{kW}$ and USD $7650 / \mathrm{kW}$ while small hydropower plants is between USD $1300 / \mathrm{kW}$ and USD $8000 / \mathrm{kW}$. If the case is adding extra capacity at existing hydropower plant the cost can be cheaper, and can cost up to USD 500/kW [9].

According to International Renewable Energy Agency (IRENA) cost analysis [9], the rehabilitating cost is 500 1000 US dollar per kilowatt. Dabena MHPP power capacity is $150 \mathrm{~kW}$ therefore the average investment cost will be 112500 US Dollar or 2.475 million Ethiopian birr.

\section{CONCLUSION}

In this research the assessment of Dabena MHP is done. Primary data from the field and secondary data from Bedelle meteorological station has been taken, analyzed and used. The civil work Components like weir size, Open Channel size, Forebay Tank size, length and diameter of the penstock were measured directly from the site survey. Using the results from this calculations the flow rate of the river in Open Channel and weir has been calculated, which are the main parameter as an input to calculate the capacity of the plant. From the meteorological data we collected from Bedelle meteorological station, we saw that during winter time the level of river will be very small and at summer time it increases due to rain fall.

We didn't find a chance to see the powerhouse because it is long time since the powerhouse is closed and we did not find the key to open it. We did an assessment on Electromechanical Components based on internationally accepted techniques. Considering different criteria, we came to the conclusion that the turbine is Cross flow turbine and the generator type is synchronous generator.

Furthermore, we have estimated the load for Bedelle campus and near local house hold.

From our assessment we came to the point to identify the current capacity of the plant and it is about $150 \mathrm{~kW}$.

The metrological data shows that rainfall increases during summer time. Thus, we can get more power during this period. But this problem can be solved by focusing on the civil work components. If we able to increase the size of fore bay tank, Weir and open Channel, their water storage capacity will be increased. As a result the chance to have more power in only summer season can be extended to winter season.

\section{SOURCES OF FUNDING}

This research received no specific grant from any funding agency in the public, commercial, or not-for-profit sectors.

\section{CONFLICT OF INTEREST}

The author have declared that no competing interests exist.

\section{ACKNOWLEDGMENT}

None.

\section{REFERENCES}

[1] AyeleNigussie, Development of a dual mode frequency controller for standalone, micro and mini hydropower systems, MSC thesis, ECE, AAIT, Ethiopia, July 2010. 
[2] Bilal Abdullah Nasir, Design considerations of micro-hydro- electric power plant, The international conference on technologies and materials for renewable energy, environment and sustainability, TMREES14, 2014.

[3] C. C. WARNICK, Hydropower engineering,Prentice-Hall, Inc.,EnglewoodCliffs,New Jersey 07632 ,USA,1984

[4] Celsopencho,Layman guidebook on how to develop a small hydro site, Small Hydropower Association (ESHA), second edition, Belgium, June, 1998.

[5] Charles Ken Adu, Boahen, Prefeasibility studies for mini hydro power generation on Kintampo falls, Kwame Nkrumah University of Science and Technology, Ghana, June 2013.

[6] http://www.voithhydro.com/media/VSHP090041_Pelton_t3341e_72dpi.pdf

[7] http://www.voithhydro.com/media/t3339e_Francis_72dpi.pdf

[8] Inversin, Allen R., Micro-Hydropower Sourcebook: A Practical Guide to Design and Implementation in Developing Countries, Intermediate Technology Publications, 1986.

[9] IRENA, Renewable energy technologies, cost analysis series, volume1, 2012

[10] J.D. McKinney, et al, Micro hydropower Handbook, volume 2, 1983

[11] Mark Tamburrini, A feasibility study for a microhydro installation for the strangford lough wildfowlers \& conservation association, MSC thesis, ME, University of Strathclyde, September 2004.

[12] MohamedWadi, A Self-Excited Synchronous Generator for Small Hydro Applications, Department of Energy and Environment, Chalmers University of Technology, Sweden,2005

[13] MuhammadAdil Khan and Saeed Badshah, Design and Analysis of Cross Flow for Micro Hydro Power Application using Sewerage Water, International Islamic University, Islamabad, Pakistan, 2014.

[14] NRC (A Buyer"s Guide), Micro-Hydropower Systems, Canada, 2004

[15] Part 1, Guide on How to Develop a Small Hydropower Plant, ESHA 2004

[16] Part 2, Guide on How to Develop a Small Hydropower Plant, ESHA 2004

[17] SmailKhennas and Andrew Barnett, Best Practices for Sustainable Development Of Micro Hydro Power In Developing Countries, Final Synthesis Report Contract R7215, 2000.

[18] TEPCO, A Module 4.3 Micro-Hydro Designing. Pacific Power Association, Nadi, Republic of the Fiji Islands, 2005. 